\title{
An Investigation of Saudi English-Major Learners' Perceptions of Formative Assessment Tasks and Their Learning
}

\author{
Muhammad Umer ${ }^{1} \&$ Abdul Majeed Attayib Omer ${ }^{2}$ \\ ${ }^{1}$ Foreign Languages Department, Faculty of Arts, Taif University, Saudi Arabia \\ ${ }^{2}$ E.L.C. College of Social Sciences, Umm AL-Qura University, Makah, Saudi Arabia \\ Correspondence: Abdul Majeed Attayib Omer, E.L.C. College of Social Sciences, Umm AL-Qura University, \\ Makah, Saudi Arabia.E-mail: drtayib@hotmail.com,m.khan@tu.edu.sa
}

\author{
Received: October 18, 2014 Accepted: November 24, 2014 Online Published: January 20, 2015 \\ doi:10.5539/elt.v8n2p109 URL: http://dx.doi.org/10.5539/elt.v8n2p109
}

\begin{abstract}
The effect of standardised and summative assessment on teaching and learning has been explored in various settings. Formative assessment or classroom assessment, however, has not captured considerable attention of washback researchers. The prime goal of the inclusion of formative assessment in the assessment regime of a curriculum is to allow learners to grow as independent learners. This study investigated if learners' perceptions of formative assessment tools influenced their learning strategies, the scope of what they learned, and the depth of their learning. The results of a survey, distributed among 400 Taif University English-major female learners (TUEMFL) showed that the respondents preferred formative assessment tasks to comprise expected questions in the form of multiple-choice questions. In addition, formative assessment tasks narrowed down the scope of the syllabus the learners studied. However, the participants deemed formative assessment helpful in diagnosing and improving their mistakes. Therefore, it is suggested that the nature formative assessment tasks should synchronise with their course objectives to help learners improve their academic skills. This may mean that the assessment tasks should be more authentic in nature and should have a greater consequential validity replacing the multiple-choice questions which often culminate in surface-level learning.
\end{abstract}

Keywords: formative assessment, learners' perceptions, learning strategies, washback

\section{Introduction}

Universities in Saudi Arabia use formative assessment along with its summative counterpart to assess their learners' performance during a course. The reason why formative assessment or small scale tests become a part of the assessment component of a curriculum is that they help learners know how far they have achieved the objectives of a course and where they have to be by the end of the course (Black \& William, 1998). Therefore, the basic purpose of formative assessment is raising the standard of learners' learning by helping them know their progress and improve themselves where needed. However, the situation is not that straightforward as it might appear on paper. There are factors that might hinder learners' successful learning despite the presence of formative assessment in a curriculum. This study attempted to investigate the factors that tended to minimise the positive effect of formative assessment in the context of Taif University, a public sector university in Saudi Arabia.

\section{Literature Review}

Washback studies have been conducted in various settings investigating the influence of tests on teaching, learning, and even learning materials, e.g., Sri Lanka (Wall \& Alderson, 1993), Japan (Watanabe, 1997, 2004), UK (Green, 2006a, 2006b, 2007), Australia (Burrows, 2004), Canada (Saif, 2006), Greece (Tsagari, 2009), China (Chu \& Gao, 2006), Hong Kong (Cheng, 2004), New Zealand (Hayes \& Read, 2004), US (Stecher, Chun \& Barron, 2004). One feature shared by all these studies has been their focus on the washback of high-stakes or standardised tests such as IELTS, TOFEL, university entrance examinations, and school-leaving certificates etc.

Previous research indicates that tests may have either positive or negative effect on teaching and learning, or even both depending on the nature of the tests and their tasks. For instance, if a test is poor it will have an undesirable effect on both teaching and learning (Alderson \& Wall, 1993). In addition, they are of the view that tests will affect the way learners learn and the depth of their learning. Nonetheless, like Cheng and Curtis (2004) 
they have argued that language tests are known, especially for their negative effect on teaching and learning which is called negative washback.

Washback literature shows that the way learners are assessed drives their learning strategies. However, the difference in the degree and depth of the influence of how different assessment tasks shape students' learning strategies may vary. Irrespective of the difference in the degree and depth of the effect, it surfaces clearly from the available body of washback literature that assessment methods bear a strong effect on how learners learn (Alderson \& Wall, 1993; Saif, 2006; Green, 2007; Gijbles, Sergers, \& Struyf, 2008). However, most of the available washback studies have investigated the effect of standardised tests on teachers and learners and very little has been explored about the influence formative assessment, particularly on learners (Watanabe, c.f. Newfield, 2005, p. 7)

Formative assessment, according to Lynch (2003), implies decisions being made concerning the progress and needs of students in a language program to determine what elements of the program are working well and what needs to be modified. Black and William (1998) have stated that formative assessment is a crucial component of classroom work. They have argued that improved formative assessment can raise the standards of learners' achievements and serve more as a teaching and learning tool rather than merely assessing learners' achievements. In addition, effective formative assessment serves as one of the best means to enhance the quality of an educational system (Sadler 1989, c.f. Gijbles \& Dochy, 2006). The open secret of all such quality improvement is the feedback given to students about their progress, i.e., informing them about where they are and where they have to be, which allows them to be better self-regulated learners eventually (Sadler, 1998; Assessment Reform Group [ARG], 2002).

Formative assessment can successfully serve all educational settings provided that it is used diligently (Black \& William, 1998). Only quantitative application of formative assessment such as giving students their grades and marks might culminate in reverse effects on learners, particularly the slow ones. Therefore, like ARG (2002), they strongly cautioned that the qualitative aspect of the feedback received by learners has to be ensured to improve their standard of learning. Empirical studies, though very limited in number, have confirmed this observation. For instance, Gijbles et al. (2008) studied university students' perceptions in Belgium concerning assessment demands through a student-survey questionnaire. Based on their findings, they have divided learning into two types: depth learning and surface-level learning. They found that examinations with short-answer questions, particularly multiple-choice questions, result in low level of intellectual abilities compared to essay-type questions which promotes higher-level intellectual abilities. Similarly, Scouller (1998) investigated the association between learners' learning strategies and their perceptions of formative assessment tasks via a three-part questionnaire together with analyzing the students' course results. Like Gijbles et al. (2008), the findings of the study led her to divide learning strategies into two kinds; surface learning and deep learning. The first strategy is based on bringing together generic facts and knowledge which does not involve adequate reflection, analysis, and originality of work whereas the learners who apply the second type of strategy show more reflection on assessment tasks and critical examination of learning materials. She found that multiple-choice-questions given in formative assessment tasks triggered surface-level learning unlike assignments and essay type questions which made the students use deep learning strategies. In addition, the study found that the students had their preferred learning styles which had a strong relationship with their perceptions of the formative assessment tasks. Likewise, Gijbels and Dochy (2006) studied the influence of formative assessment on learners' learning strategies and their preferences with regard to formative assessment tests. Like the two studies reported above, the researcher in this study used a student-survey questionnaire for collecting data from 108 undergraduate students. The results showed that the learners' preferences about assessment had a clear effect on their learning strategies, e.g., not showing any likeness for those assessment tasks that could examine higher-order academic skills which involved analysing, reflection and synthesis of information.

In a nutshell, one of the factors hindering the desired effect of formative assessment is learners' narrow perception of assessment tasks which, finally, shape their learning strategies (Tsagari, 2009). Since students are one of the most important stakeholders of a "testing community" (Saville \& Hawkey, 2004), their perceptions cannot be ignored. Their perceptions have been noted to have a strong impact on teachers' teaching strategies too. For example, Vallette (1994, c.f. Chen, 2002, p. 32) has argued that in education environments where "students' performance on a test determines future career options...teachers often feel obliged to teach for the test". The results of Qi (2004) have confirmed the argument of Vallette (1994) who has found that though the examination required the teachers to develop the students' communicative skills, the teachers focused on "decontextualized linguistic" materials because they believed that by not doing so both students and parents would complain that 
the material taught in school did not look like the forthcoming expected assessment tasks. Keeping in view the significance of the relationship that exists between learners' perceptions of assessment tasks and their learning strategies, the current study attempted to investigate how Taif University English major female students' perceptions of formative assessment tasks influenced their learning strategies and in what ways.

\section{Research Questions}

1) Is there any significant relationship between Taif University English major female students' perceptions of formative assessment tasks and their learning strategies?

2) Is there any significant relationship between Taif University English major female students' perceptions of formative assessment tasks and the scope of the learning materials they use?

3) Is there any significant relationship between Taif University English major female students' perceptions of formative assessment tasks and the depth of their learning?

\section{Method}

The researcher used survey as a research strategy to investigate the learners' perceptions of formative assessment methods used at Taif University (Denscombe, 2007). The instrument used to measure their perceptions and opinions was a self-reporting questionnaire with 24-five-point Likert scale items to investigate the learners' preferences with regard to quizzes, presentations, and mid-term examinations and the reasons behind their preferences and their association with the learners' learning strategies and the learning materials they studied. The items on the scale were coded as Strongly Disagree, Disagree, Undecided, Agree, and Strongly Agree.

For the face validity check of the instrument, it was given to three senior colleagues in the department of foreign languages of the university. Their feedback was incorporated. Keeping in mind the learners' low level of English the questionnaire was translated into Arabic. Thereafter, for the reliability check, the questionnaire was piloted among 30 second year English-major female learners. However, this group was not given the questionnaire during the main study. The pilot data were entered to Microsoft Excel from where it was transferred to SPSS (17). The Cronbach's alpha of the total items was 0.7277 which showed an acceptable level of internal consistency or reliability being above 0.70 .

The population of the study comprised Taif University undergraduate students who followed the same assessment method as the sample did and the English-major female students served as a purposive sample for the study. Therefore, the questionnaire was distributed among the 400 students studying in the Department of Foreign Languages (FLD) of the university at the time of the study. Non-probability purposive sampling technique was used (Denscombe, 2007). The questionnaire was returned by 289 participants with the return rate of $72 \%$. The responses were analyzed with the help of SPSS 17 for frequencies, percentages and standard deviation.

\section{Results}

Table 1. Items ranked very high by the participants

\begin{tabular}{lllll}
\hline No & Item & Cases & Mean & SD \\
\hline 1 & Recommended course books & 289 & 4.1849 & 1.00603 \\
3 & Specific pages and paragraphs & 289 & 4.5336 & .76647 \\
8 & True/false and multiple-choice questions & 289 & 4.0714 & 1.13216 \\
9 & MCQs are easy to answer. & 289 & 4.1597 & 1.07117 \\
10 & MCQs helpful to getting good grades & 289 & 4.1387 & 1.06423 \\
11 & Memorising materials & 289 & 3.8025 & 1.07860 \\
12 & No good job if grades are low & 289 & 3.9076 & 1.21518 \\
18 & Expressing personal ideas, experience and knowledge & 289 & 3.8655 & .98875 \\
20 & Knowing progress on the course and improvement & 289 & 4.1092 & .94837 \\
22 & Improving reading and writing skills & 289 & 3.9748 & 1.15076 \\
\hline
\end{tabular}


Table 1 indicates that some of the questionnaire items were ranked very high by the participants. Most of them highly agreed that they used a single course to study for the formative assessment tasks given in the midterm examinations, quizzes, and presentations. They have further reported that they preferred their teachers to inform them about the exact pages of the book that would cover the assessment tasks or questions. In addition to preferring very limited amount of learning materials, they showed a strong preference MCQs in assessment tasks. MCQs, from their point of view, are easier to answer and allow them to get good grades. Achieving good grades help them in getting good jobs. However, at the same time most of them also view the formative assessment tasks as a source of learning. For example, they agreed that the midterm examinations and quizzes helped them know their mistakes together with improving the standard of their learning, particularly reading and writing skills. Furthermore, they think that essay type questions are better than MCQs, because such questions allow them to use their own ideas and experiences.

Table 2. Items ranked high

\begin{tabular}{lllll}
\hline No & Items & Cases & Mean & SD \\
\hline 4 & No understanding of learning materials & 289 & 3.6050 & 1.20979 \\
5 & Memorising longer texts & 289 & 3.4580 & 1.37960 \\
7 & Easy to pass quizzes and mid-term exams even if I do not & 289 & 3.3361 & 1.26476 \\
& understand what my teachers teach me in class & & & \\
15 & Difficult to answer essay-type questions & 289 & 3.1723 & 1.28926 \\
16 & Essay writing is difficult because of spellings & 289 & 3.3277 & 1.36013 \\
17 & Essay writing is difficult because of lack of ideas & 289 & 3.2857 & 1.36034 \\
19 & Final exam is more important than midterm & 289 & 3.5798 & 1.35942 \\
21 & Similar learning strategies for final exams and midterm & 289 & 3.7773 & 1.01299 \\
\hline
\end{tabular}

Table 2 includes the items ranked high mean. For example, the first item in the table shows that a majority of the learners memorised material even if they did not understand it. In addition, they reported that they passed their courses without adequate understanding of the materials they studied. However, if the assessment tasks happened to be of essay-type it was difficult for them to solve the tasks. The main reason they gave for not being able to pass essay-type questions was their weak spellings and insufficient grammatical competence to compose correct sentences. The most interesting perception of the respondents was with regard to the final assessment which they considered more important compared to its formative counterpart. Furthermore, they reported that they applied the same learning strategy for the final examinations that they used formative assessment, i.e., memorising materials.

Table 3. Items ranked moderately

\begin{tabular}{lllll}
\hline No & Items & Cases & Mean & SD \\
\hline 2 & Studying different aspects of a topic & 289 & 2.9202 & 1.38327 \\
6 & The reason of losing grades & 289 & 2.7511 & 1.45601 \\
13 & Grades more important than English & 289 & 2.5210 & 1.44578 \\
14 & Essay-type questions difficult to answer & 289 & 2.5672 & 1.36321 \\
23 & Worried about tests & 289 & 2.2269 & 1.29222 \\
24 & Worried for the final exams only & 289 & 2.4412 & 1.38204 \\
\hline
\end{tabular}

Six of the questionnaire items as shown in Table 3 were ranked moderately by the respondents. For instance, with regard to the depth of their learning, the respondents reported that many of them did not try to understand what they studied from different aspects and did not use more than one source or book. The reason they gave for why they did not solve the formative assessment tasks in their own language was the fear of losing grades. This finding seems to be related with the result of item number 12 in table 3 where they reported difficulty in getting 
jobs if their grades were low. Besides, some of the participants thought that it was more important for them to have good grades than good English to get a good job. Finally, the respondents reported that almost half of them worried about the final assessment more than its summative counterpart, i.e., quizzes, midterm examinations and writing assignments.

\section{Discussion}

The findings of previous research strongly suggest that assessment tasks will influence students' learning strategies and the learning materials they study (Alderson \& Wall, 1993). With regard to formative assessment in particular, past research shows that learners' perceptions of assessment tasks play a strong role in shaping their learning strategies (Vallette, 1994; Qi, 2004). The findings of this study confirmed that the respondents expected and preferred the formative assessment tasks to be easy, having multiple-choice questions rather than essay-type questions which they deemed difficult to attempt because of their weak writing skills such as poor vocabulary, spellings, and weak grammar. In addition, the participants strongly agreed that they applied memorisation as a learning strategy not only for the during-the-course assessment, namely; quizzes, midterm exams, and presentations, but also for the final examinations. Thus, they reported the interesting as well as alarming truth that they memorised materials and managed to pass the tests, sometimes with no understanding. This shows that they preferred to pass the assessment tasks by all means and considered passing the tests as an end of coming to the university. The evidence gathered strongly indicates that it did not seriously matter for the students whether they understood what they were taught as long as they managed to pass. Hence, this study confirmed that learners' learning strategies have a correlation with how they are assessed (Tsagari, 2009; Watanabe, 1997; Qi, 2004). Munoz and Alvarez (2010) have stated that one of the weaknesses of multiple-choice assessment tasks is that they encourage students to memorize materials. In such a situation, teachers while grading students' answers cannot easily decide if their students have actually understood the concepts. Therefore, assessment tasks should be authentic to allow learners to apply what they have been taught to new situations (Messick, 1996).

Previous research shows that the nature of assessments tasks influence learning materials. One type of influence is the narrowing down of the scope of the learning materials being studied. For example, Ferman (2004) has found that formative assessment tasks can also constrict the scope of materials that students learn. The results of the present study confirmed that the formative assessment methods in the context of this study appeared to make the students studied a very limited part of the learning materials they were supposed to study. A big majority of the survey respondents agreed with the statement ' I like to know the specific pages and paragraphs that will cover the questions of quizzes and midterm exams'. This situation seconds the finding of Ferman (2004) that the scope of learning materials can be narrowed down to an undesirable extent by formative assessment too. One of the solutions of the problem is to have a greater congruence between the objectives of a course and the assessment tasks (Green, 2007) which allows learners to apply the skills they learn to new situations instead of encouraging the memorisation of a limited amount of materials to pass a course.

Alderson and Wall (1993) stated that tests will affect the depth of what learners' learn. This hypothesis has strongly been supported by Stecher et al. (2004) that performance-based assessment results in deep learning whereas multiple-choice questions result in surface-level learning (Gijbles et al., 2008). The current research showed that the respondents did not benefit fully from the formative assessment tools. They memorised materials and preferred MCQs. Furthermore, they mostly relied on a single course book or even a few pages of books to pass tests. This shows that there is a serious need to make sure that the formative tests students get have a high level of content validity.

\section{Conclusion and Recommendations}

The findings of this small-scale-case study may not be easily generalisable to other similar settings; however, it did highlight the need of further empirical research in the area of formative assessment, particularly in traditional educational settings where tangible differences between formative and summative assessment at operational level do not exist. The results confirmed that respondents' preferences and perceptions of formative assessment methods tend to have a significant effect on their learning (Gibels \& Dochy, 2006; Scouler, 1998). The findings robustly confirm that only improved formative assessment can raise the standard of learning (Black \& William, 1998). Formative assessment for the sake of formative assessment may not necessarily have any positive washback on students' learning. In addition, factors beyond classroom situations such as job providers (Saville \& Hawkey, 2004) also seem to have a role in shaping the effect of formative assessment tasks on learners in this context more or less in the same way as they do in the contexts of exotic tests (Watanabe, 1997; Cheng, 2004). Therefore, like standardised tests, formative assessment tools deserve a serious attention of washback researchers (Watanabe, c.f. Newfield, 2005, p. 7) and there must be further empirical research in the area to help teachers, 
school administrators, and policy makers make the most of formative assessment by raising the standard of students' learning.

\section{References}

Alderson, J. C., \& Wall, D. (1993). Does washback exist? Applied Linguistics, 14(2), 115-129.

Assessment Reform Group. (2002). Assessment for learning: Research-based principles to guide classroom practice.

Black, P., \& William, D. (1998). Inside the black box. Phi Delta Kappan, 80(2), 139-148.

Bose, J., \& Rengel, Z. (2009). A model formative assessment strategy to promote student-centred self-regulated learning in higher education. US-China Education Review, 6(12), 29-35.

Burrows, C. (2004). Washback in classroom-based Assessment: A study of the washback effect in the Australian adult migrant English program. In L. Cheng, Y. Watanabe, \& A. Curtis (Eds.), Washback in language testing: Research context and methods (pp. 113-128). London: Lawrence Erlbaum Associates.

Chen, L. (2002). Washback of a public exam on English teaching. (ERIC Document Reproduction Service No. ED472167).

Cheng, L. (1999). Changing assessment: Washback on teacher perceptions and actions, teaching and teacher education. Elsevier Science, 15, 253-271.

Cheng, L., \& Curtis, A. (2004). Washback or backwash: A Review of the impact of testing on teaching and learning. In L. Cheng, Y. Watanabe, \& A. Curtis (Eds.), Washback in language testing: Research context and methods (pp. 3-17). London: Lawrence Erlbaum Associates.

Chu, L., \& Gao, P. (2006). An empirical study of the washback of CET-4 writing. Sino-US English Teaching, 3(5), 36-38.

Denscombe, M. (2007). The good research guide: For small-scale social research project (3rd ed.). Buckingham: Open University Press.

Ferman, I. (2004). The washback of an EFL national oral matriculation test to teaching and learning. In L. Cheng, Y. Watanabe, \& A. Curtis (Eds.), Washback in language Testing: Research context and methods (pp. 191-210). London: Lawrence Erlbaum Associates.

Gijbels, D., \& Dochy, F. (2006). Students' assessment preferences and approaches to learning: Can formative assessment make a difference? Educational Studies, 32(4), 399-409.

Qi, L. (2004). Has a high-stakes test produced the intended changes? In L. Cheng, Y. Watanabe, \& A. Curtis (Eds.), Washback in language Testing: Research context and methods (pp. 171-190). London: Lawrence Erlbaum Associates.

Gijbles, D., Segers, M., \& Struyf, E. (2008). Constructivist learning environments and the (im)possibility to change students' perceptions of assessment demands and approaches to learning. Instr. Sci., 36, 431-443.

Green, A. (2006a). Washback to the learner: Learner and teacher perspectives on IELTS preparation course expectations and outcomes. Assessing Writing, 11(2), 113-134.

Green, A. (2006b). Watching for washback: Observing the influence of the International English Language Testing System academic writing test in the classroom. Language Assessment Quarterly, 3(4), 333-367.

Green, A. (2007). IELTS washback in context: Preparation for academic writing in higher education. Cambridge: Cambridge University Press.

Lynch, B. K. (2003). Language assessment and program evaluation. Edinburgh: Edinburgh University Press.

Messick, S. (1996). Validity and washback in language testing. Language Testing, 13(3), 241-256.

Mohammed, C. Z. J. A. (2010). Assessment of ESP course contents for medical students: A case study of medicine students (Unpublished $\mathrm{PhD}$ thesis), Jezira University. Taif University, KSA.

Muñoz, A. P., \& Álvarez, M. E. (2010). Washback of an oral assessment system in the EFL classroom. Language Testing, 27(1), 33-49.

Newfields, T. (2005). Voices in the Field: An interview with Yoshinori Watanabe. SHIKEN: JALT Testing \& Evaluation SIG Newsletter, 9(1), 5-7.

Sadler, D. R. (1998). Formative assessment: Revisiting the territory. Assessment in Education, 5(1), 77-84. 
Saville, N., \& Hawkey, R. (2004). The IELTS impact study: Investigating washback on teaching materials. In L. Cheng, Y. Watanabe, \& A. Curtis (Eds.), Washback in language Testing: Research context and methods (pp. 73-96). London: Lawrence Erlbaum Associates.

Saif, S. (2006). Aiming for positive washback: A case study of international teaching assistants. Language Testing, 23(1), 1-34.

Saville, N., \& Hawkey, R. (2004). The IELTS impact study: Investigating washback on teaching materials. In L. Cheng, Y. Watanabe, \& A. Curtis (Eds.), Washback in language Testing: Research context and methods (pp. 73-96). London: Lawrence Erlbaum Associates.

Scouller, K. (1998). The influence of assessment method on students' learning approaches: Multiple choice question examination versus assignment essay. Higher Education, 35, 453-472.

Stecher, B., Chun, T., \& Barron, S. (2004). The effects of assessment- driven reform on the teaching of writing in Washington State. In L. Cheng, Y. Watanabe, \& A. Curtis (Eds.), Washback in language testing: Research context and methods (pp. 53-71). London: Lawrence Erlbaum Associates.

Tsagari, D. (2009). Revisiting the concept of test washback: Investigating FCE in Greek language schools. Cambridge ESOL, Research Notes, 35, 5-9.

Wall, D., \& Alderson, J. C. (1993). Examining washback: The Sri Lankan impact study. In A. Cumming, \& R. Berwick (Eds.), Validation in language testing (pp. 194-221). Bristol, USA: Multilingual Matters.

\section{Copyrights}

Copyright for this article is retained by the author(s), with first publication rights granted to the journal.

This is an open-access article distributed under the terms and conditions of the Creative Commons Attribution license (http://creativecommons.org/licenses/by/3.0/). 